\title{
Bio-mineralogy as a structuring factor for marine epibenthic communities
}

\author{
G. Bavestrello ${ }^{1, *}$, C. N. Bianchi ${ }^{2}$, B. Calcinai ${ }^{3}$, R. Cattaneo-Vietti ${ }^{3}$, C. Cerrano ${ }^{3}$,

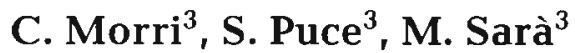 \\ 'Istituto di Scienze del Mare, Università di Ancona, Via Brecce Bianche, 60131 Ancona, Italy \\ ${ }^{2}$ Marine Environment Research Centre, ENEA Santa Teresa, PO Box 316, 19100 La Spezia, Italy \\ ${ }^{3}$ Dipartimento per lo studio del Territorio e delle sue Risorse, Università di Genova, Viale Benedetto XV 5 , \\ 16132 Genova, Italy
}

\begin{abstract}
The mineralogical features of the substrate were generally considered a minor factor in structuring marine benthic communities. The aim of this work is to verify whether the presence of quartz minerals in rock may explicate differences, usually explained in terms of substrate roughness or other factors, in epibenthic communities. Laboratory tests on the hydroid Eudendrium glomeratum showed that its planulae settle preferentially on carbonatic, rather than quartzitic, substrates. To test the influence of quartz on established communities, we analysed the species composition and quantitative structure of sublittoral sessile assemblages on different rocks in several localities of the Ligurian and Tyrrhenian seas. The observed differences appeared to be related to the presence of quartz in the substrate rock. The interactions between organisms and minerals (bio-mineralogy) might play a significant role on benthic communities, affecting not only the initial colonisation, but also later assemblages. This potential role has been largely neglected to date and further studies are needed to prove its importance.
\end{abstract}

KEY WORDS: Substrate colonisation - Mineral composition . Marine benthos distribution - Hard substrates - Bio-mineralogy

\section{INTRODUCTION}

The spatial distribution and structure of marine benthic communities are due to numerous abiotic and biotic factors which, in turn, are influenced by the presence of the organisms, in a mutual exchange of inputs. Among the abiotic factors, the mineralogical features of the substrate were generally considered of scarce importance, but recent studies by Cerrano et al. (1998) have shown that the presence of quartz in the sand may affect the initial steps of infauna colonisation. Cerrano et al. (1998) introduced the term bio-mineralogy to explicate the interrelationships between biological systems at different hierarchies (cell, organism, species, community) and minerals.

Bio-mineralogy could influence hard-bottom assemblages and explain some 'anomalies' in the structure of

-E-mail: bave@promix.it communities growing on rocks of different nature. A species assemblage, which may be slightly more attracted to a particular substrate, could affect succession by its subsequent interaction with later assemblages. A similar effect was evidenced in the colonisation of artificial substrates, with respect to both species composition and abundance (Anderson \& Underwood 1994, Holm et al. 1997). Less information is available for natural substrates (McGuiness 1989), but it is common knowledge that the softness and asperity of a rock can favour or hamper biotic colonisation through selective larval settling, retention of water (in the littoral) and organic matter, and provision of refuges from predation or grazing (Den Hartog 1972, Levinton 1982, Walters \& Wethey 1996).

More is known about the influence of substrate mineralogy on bioboring, which is prevented by high percentages of quartzitic or pelitic components in the rock. Sublittoral endolitic communities are charac- 


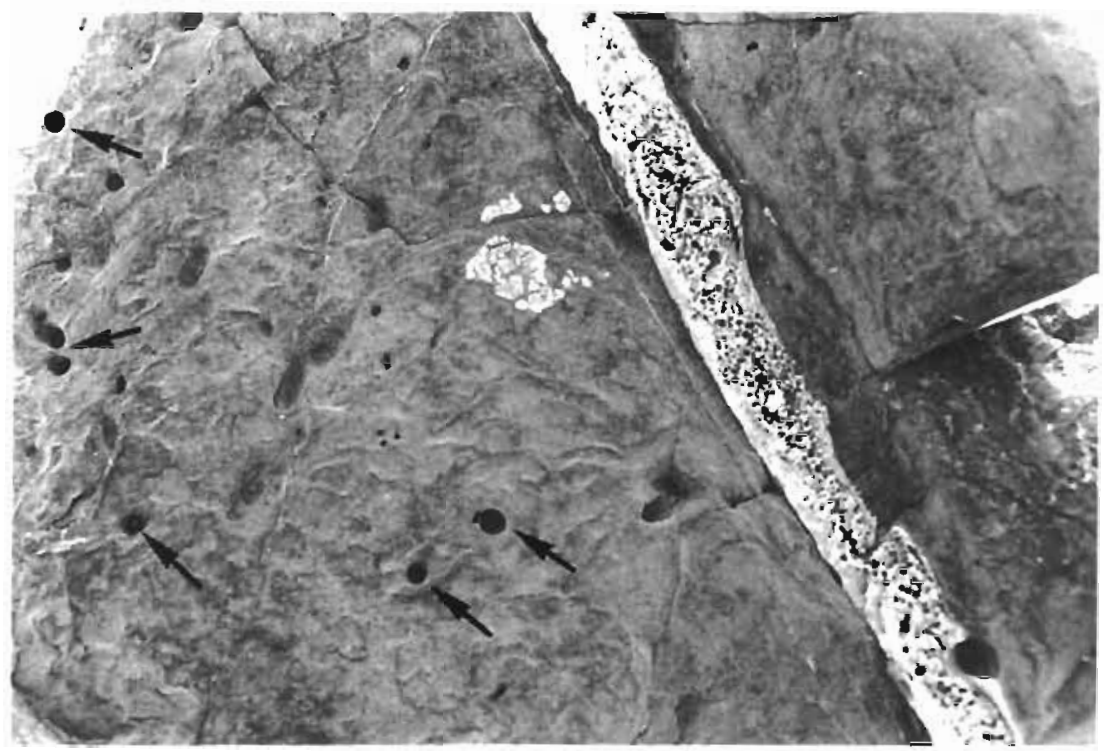

Fig. 1. Sublittoral rock showing differences in the distribution of borers due to the mineral composition of the substrate. The white calcitic vein is widely bored by the sponge Cliona celata which is absent on marl limestone (grey). Herein only the datemussel Lithophaga lithophaga is able to penetrate (arrows) during November 1998 at 20 to $25 \mathrm{~m}$ depth. The fertilised eggs develop in verticils of 5 to 10 fixed to a rudimentary polyp, the blastostyle, deprived of mouth and tentacles. Each egg is enveloped by a non-branched spadix. The verticils of eggs were mechanically detached from the mother colony and placed in $250 \mathrm{ml}$ cups filled with filtered natural sea water at a temperature of $15^{\circ} \mathrm{C}$.

Cerrano et al. (1997) demonstrated that light exposure is necessary to trigger egg hatching and therefore we reared the eggs in lit conditions for $3 \mathrm{~d}$. New released planulae were divided into 4 stocks of 60 specimens and each stock was placed for $12 \mathrm{~d}$ in an experimental Petri dish in complete darkness to avoid problems related to their very high phototrophy. Petri dishes were prepared by sticking a uniform layer

terised mainly by clionid sponges and bivalves. Clionid sponges use hatching cell pseudopodes and the production of carbonic acid to penetrate limestone (Rüzler \& Rieger 1973, Pomponi 1979), but Cliona celata Grant preferentially bores, in the Mediterranean Sea. substrates richer than $60 \%$ in carbonates (unpubl obs.). Bivalves, such as species of Lithophaga, bore with the help of sulphuric acid and/or neutral mucoproteins (Russo \& Cicogna 1992), and are also able to penetrate marl limestone, which is impenetrable by clionids (unpubl. obs., Fig. 1). All this has important consequences on the rock texture and roughness and, ultimately, on the community structure.

To check the influence of substrate mineralogy on the larval settling, a series of laboratory tests was conducted using planulae of the hydroid Eudendrium glomeratum (Picard), a very common species of the sublittoral Mediterranean zoobenthos (Boero et al. 1986). In order to seek a relation between the mineralogy of natural substrates and the structure of sessile epibenthic communities, the species composition and percent cover of assemblages living on different kinds of rock in the western Mediterranean Sea were compared.

\section{MATERIAL AND METHODS}

Laboratory. Planulae of the hydroid Eudendrium glomeratum were obtained from female colonies collected on the rocky cliff of the Portofino Promontory of sand grains with Eukitt; half of the surface was covered by quartz sand, and half by sand derived from Carrara marble. The 2 sand types have the same granulometric (125 to $250 \mu \mathrm{m}$ ) and morphological features (roundness, 0.35 to 0.7 ; projection of sphericity, 0.8 to

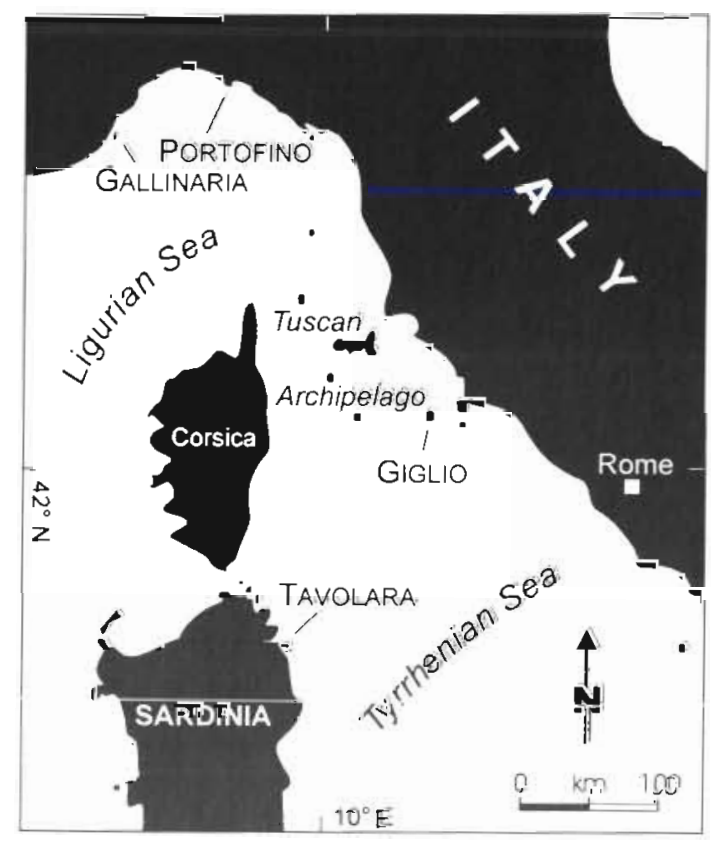

Fig. 2. Geographic layout of the field-study sites in the Ligurian and Tyrrhenian seas (NW Mediterranean) 
Table 1. Localities for field studies on sublittoral rocky bottoms

\begin{tabular}{|c|c|c|c|c|c|c|}
\hline \multirow{2}{*}{$\begin{array}{l}\text { Locality } \\
\text { Ligurian Sea }\end{array}$} & \multicolumn{3}{|c|}{ Contrasted mineralogies } & \multirow{2}{*}{$\begin{array}{l}\text { Depth } \\
\text { range }(\mathrm{m}) \\
5-7\end{array}$} & \multirow{2}{*}{$\begin{array}{c}\text { No. of } \\
\text { stations }\end{array}$} & \multirow{2}{*}{$\begin{array}{c}\begin{array}{c}\text { No. of } \\
\text { species }\end{array} \\
60\end{array}$} \\
\hline & $\begin{array}{c}\text { Quartzite } \\
\text { (Gallinaria Island) }\end{array}$ & vs & $\begin{array}{l}\text { Puddingstone, marl } \\
\text { limestone and sandstone } \\
\text { (Portofino region) }\end{array}$ & & & \\
\hline Giglio Island & $\begin{array}{l}\text { Granite (most of } \\
\text { the island) }\end{array}$ & vs & $\begin{array}{c}\text { Limestone (western part } \\
\text { of the island) }\end{array}$ & $6-10$ & 16 & 54 \\
\hline Northeast Sardinia & $\begin{array}{l}\text { Granite (most of the } \\
\text { coast and small islands) }\end{array}$ & vs & $\begin{array}{l}\text { Limestone-dolomite } \\
\text { (Tavolara Island) }\end{array}$ & $18-34$ & 20 & 44 \\
\hline
\end{tabular}

0.9). Both kinds of sand were previously stored at $100^{\circ} \mathrm{C}$ for $24 \mathrm{~h}$, which enabled us to obtain an artificial hard bottom on the entire Petri dish surface, with very similar physical features but with 2 different mineralogies.

Field. The data matrices were produced using unpublished data sets on subtidal epibenthic communities of the Ligurian Sea (Gallinaria Island and Portofino region) and Tyrrhenian Sea (Giglio Island and northeast Sardinia) (Fig. 2). The data sets were chosen in order to be able to contrast communities from an equal number of stations on rocks rich in quartz, such as quartzite and granites, or deprived of that mineral (Table 1). All data sets consist of percent cover data of conspicuous species (Hiscock 1987), derived from underwater visual inventories by SCUBA divers using quadrats (Bianchi et al. 1991). Cover data for a total of 96 species (Table 2) were available, but each data set was analysed separately according to depth zone and geographical location, so that communities only showed differences in the mineralogical nature of the substrate and possibly exposure. To avoid the influence of sedimentation, which may alter the effects of mineralogical composition at the rock surface (Bavestrello et al. 1995a), vertical stations (70 to $95^{\circ}$ slope) were selected. Matrices of species cover data were compared by correspondence analysis (Legendre \& Legendre 1998), and species numbers and total cover by 1 -way ANOVA. Prior to analysis, percentage cover values were arcsine transformed to meet the assumption of homogeneity of variances (Underwood 1997).

Field-study sites. The Ligurian Sea data derive from surveys carried out in shallow water at Gallinaria Island in the summer of 1991 and in the region of Portofino Promontory in the summer of 1993. The Tyrrhenian Sea data include information taken at infralittoral depths around Giglio Island in September of 1988 to 1991 and at circalittoral depths in northeastern Sardinia in June 1990 (Table 1).

The Ligurian Sea has been the object of much research in marine biology, and many studies have taken into account the epibenthic communities on the rocky bottom (Bianchi et al. 1987, Cattaneo-Vietti et al. 1988 ). One of the most studied sites is the region around Portofino (Tortonese 1958, 1962, Morri et al. 1988), but recent research has also been done on the Island of Gallinaria (Balduzzi et al. 1994). These studies underlined that epibenthic communities on sublittoral rocks at Portofino are dominated by flourishing gorgonian populations, whereas at Gallinaria, gorgonians are scarce and sponges dominate. From a mineralogical point of view, Gallinaria Island is exclusively quartzitic (Orsino 1975), whereas the coast around Portofino is characterised by puddingstone, marl limestone and sandstone, none of which has a significant quartz component (Boni et al. 1969).

The Giglio Island is included in the southern group of the Tuscan Archipelago, at the border between Ligurian and Tyrrhenian seas. Its rocky coast is mostly granite, but a small portion on the western side is composed of limestone (Alvisi et al. 1994). The subtidal epibenthic communities of Giglio Island were first described by Balduzzi et al. (1996).

The northeast corner of Sardinia is mostly composed of granite. A striking exception is the Tavolara Island made by a gigantic limestone-dolomite slab (Lorenzoni \& Chiesura-Lorenzoni 1973). Together with Molara, Molarotto and other minor islets and rocks (all granitic), Tavolara forms a small archipelago, the epibenthic communities of which have been studied by Navone et al. (1992).

\section{RESULTS}

\section{Laboratory}

After hatching, the Eudendrium glomeratum planulae crawled on the bottom of culture vessel for 2 to $3 \mathrm{~d}$. Then, they fixed to the substrate by the anterior pole and metamorphosed into a planulary polyp. Data showed that crawling planulae had a strong selectivity for the substrate, being always about 5 times more abundant on the 
Table 2. List of the species in inventories of field studies on sublittoral rocky bottoms. Species codes are those used in Figs. $4,6 \& 7$

\begin{tabular}{|c|c|c|c|c|c|}
\hline Code & Species/family name & Phylum & Code & Species/family name & Phylum \\
\hline$A a b$ & $\begin{array}{l}\text { Acetabulana acetabulum (Linnaeus) } \\
\text { P. C. Silva }\end{array}$ & Chlorophyta & $\begin{array}{l}\text { lor } \\
\text { IrC }\end{array}$ & $\begin{array}{l}\text { Ircinia oros (Schmidt) } \\
\text { Ircinia sp. }\end{array}$ & $\begin{array}{l}\text { Ponfera } \\
\text { Porifera }\end{array}$ \\
\hline AaC & Acanthella acuta Schmidt & Porifera & Iva & Ircina variabilis (Schmidt) & Porifera \\
\hline Acr & Amphiroa cryptarthrodia Zanardinı & Rhodophyta & $J r u$ & Janıa rubens (Linnaeus) Lamouroux & Rhodophyta \\
\hline Ada & Axunella damicomis (Esper) & Porifera & Lfr & Lithophyllum frondosum (Dufour) Furnari, & Rhodophyta \\
\hline Ali & Arbacia lixula (Linnaeus) & Echinodermata & & Cormaci et Alongi & \\
\hline Aor & Agelas oroides (Schmidt) & Porifera & Lin & Lithophyllum incrustans Philippı & Rhodophyta \\
\hline Ari & Amphiroa rigida Lamouroux & Rhodophyta & Lob & Laurencia obtusa (Hudson) Lamouroux & Rhodophyta \\
\hline Ave & Axinella verrucosa (Esper) & Porifera & $L p r$ & Leptopsammia pruvoti Lacaze-Duthiers & Cnidaria \\
\hline Beu & Balanophyllia europaea (Risso) & Cnidaria & Lva & Leucosolenja variabilis Haeckel & Porifera \\
\hline Bpe & Balanus perforatus Bruguière & Arthropoda & Mli & Mesophylum lichenoides (Ellis) Lemoine & Rhodophyta \\
\hline Cad & Codium adhaerens C. Agardh & ChJorophyta & Mt. & Myriapora truncata (Pallas) & Bryozoa \\
\hline Cbo & Caberea boryi (Audouin et Savigny) & Bryozoa & Mvu & Microcosmus vulgaris Heller & Chordata \\
\hline Cbu & Codium bursa (Linnaeus) C. Agardh & Chlorophyta & $\operatorname{Pax}$ & Parazoanthus axinellae (Schmidt) & Cnidaria \\
\hline $\mathrm{Ccl}$ & Clathrina clathrus (Schmidt) & Porifera & $P_{C l}$ & Paramuricea clavata (Risso) & Cnidaria \\
\hline Cco & Clathrina contorta (Bowerbank) & Porifera & PCO & Parerythropodium coralloides (Pallas) & Cnidaria \\
\hline $\mathrm{Crr}$ & Crambe crambe (Schmidt) & Porifera & PCr & Palmophyllum crassum (Naccari) & Chlorophyta \\
\hline Cole & Clavelina dellavalles (Zirpolo) & Chordata & & Rabenhorst & \\
\hline $\mathrm{Cel}$ & Corallina elongata Ellis et Solander & Rhodophyta & $P_{f a}$ & Pentapora fascialis (Pallas) & Bryozoa \\
\hline $\mathrm{Cfl}$ & Cellana fistulosa (Linnaeus) & Bryozoa & $P_{f i}$ & Petrosia ficiformis (Poiret) & Porlfera \\
\hline$C t r$ & Codium fragle (Suringar) Hariot & Chlorophyta & Pft & Phorbas fictitius (Bowerbank) & Porifera \\
\hline Cgr & Corallina granifera Ellis et Solander & Rhodophyta & Pfu & Pseudochlorodesmis furcellata & Chlorophyta \\
\hline $\mathrm{Cin}$ & Caryophylha inornata (Duncan) & Cnidaria & & (Zanardmı) Borgesen & \\
\hline $\mathrm{Cla}$ & Cladophara sp. & Chlorophyta & $P h$ & Paracentrotus lividus (Lamarck) & Echinodemata \\
\hline $\mathrm{Cln}$ & Clionidae spp. & Porifera & Pne & Phyllophora nervosa (De Candolle) & Rhodophyta \\
\hline $\mathrm{Cmu}$ & Cutleria multifida (Smith) Greville & Phaeophyta & & Greville ex J. Agardh & \\
\hline Cni & Cliona nigricans (Schmidt) & Porifera & Ppa & Padina pavonica (Linnaeus) Lamouroux & Phaeophyta \\
\hline Cnu & Chondrilla nucula Schmıdt & Porifera & $\rho_{5 Q}$ & Peyssonnelia squamaria (Gmelin) & Rhodophyta \\
\hline Cpa & Chartella papyrea (Pallas) & Bryozoa & & Decaisne & \\
\hline$C p r$ & Cladophora prolifera (Roth) Kützıng & Chlorophyta & Pte & Phorbas tenacior (Topsent) & Porifera \\
\hline Cre & Chondrosia reniformis Nardo & Ponfera & Ptr & Pomatoceros triqueter (Linnaeus) & Annelida \\
\hline Csp & $\begin{array}{l}\text { Cladostephus spongiosus (Hudson) } \\
\text { C. Agardh }\end{array}$ & Phaeophyta & $\begin{array}{l}\text { Plu } \\
\text { Rfu }\end{array}$ & $\begin{array}{l}\text { Protula tubulana (Montagu) } \\
\text { Renuesa fulva Topsent }\end{array}$ & $\begin{array}{l}\text { Annelida } \\
\text { Ponfera }\end{array}$ \\
\hline $\mathrm{CZO}$ & $\begin{array}{l}\text { Cystoseira zosterosdes (Turner) } \\
\text { C. Agardh }\end{array}$ & Phaeophyta & $\begin{array}{l}\text { Rhy } \\
\text { Rvi }\end{array}$ & $\begin{array}{l}\text { Rhyncozoon sp. } \\
\text { Reptadeonella violacea (Johnston) }\end{array}$ & $\begin{array}{l}\text { Bryozoa } \\
\text { Bryozoa }\end{array}$ \\
\hline$D d i$ & Dictyota dichotoma (Kudson) Lamouroux & Phaeophyta & Sar & Serpulorbis arenaria (Linnaeus) & Mollusca \\
\hline Dpo & $\begin{array}{l}\text { Dictyopteris polypodioldes (De Candolle) } \\
\text { Lamouroux }\end{array}$ & Phaeophyta & $\begin{array}{l}\text { Sau } \\
\text { Sce }\end{array}$ & $\begin{array}{l}\text { Schizomavella auriculata (Hassall) } \\
\text { Smittina cervicornis (Pallas) }\end{array}$ & $\begin{array}{l}\text { Bryozoa } \\
\text { Bryozoa }\end{array}$ \\
\hline $\begin{array}{l}\text { Dve } \\
\text { Dvt }\end{array}$ & $\begin{array}{l}\text { Dasycladus vermicularis (Scopoli) Krasser } \\
\text { Dudresnaia verticillata (Withering) } \\
\text { Le Jolis }\end{array}$ & $\begin{array}{l}\text { Chlorophyta } \\
\text { Rhodophyta }\end{array}$ & Sco & $\begin{array}{l}\text { Sphaerococcus coronopifolius } \\
\text { (Goodenough et Woodward) C. Agardh } \\
\text { Spirastrella cunctatrix Schmidt }\end{array}$ & Rhodophyta \\
\hline Eca & Eunicella cavolinil (Koch) & Cnidaria & $S d y$ & Salmacina dysteri (Huxley) & Annelida \\
\hline $\begin{array}{l}\text { Era } \\
\text { Esi }\end{array}$ & $\begin{array}{l}\text { Eudendrium racemosum (Gmelın) } \\
\text { Eunicella singularis (Esper) }\end{array}$ & $\begin{array}{l}\text { Cnidaria } \\
\text { Cnidaria }\end{array}$ & Sel & $\begin{array}{l}\text { Sertularella ellisil (Deshayes et } \\
\text { Milne-Edwards) }\end{array}$ & Cnidaria \\
\hline Fpe & Flabellia petiolata (Turra) Nizamuddın & Chlorophyta & ser & Unidentified serpulids & Annelida \\
\hline Fru & 'Falkenbergia rufolanosa' (Fłarvey) Schmitz & Rhodophyta & Sla & Savignyella lafontii (Audouin et Savigny) & Bryozoa \\
\hline Gob & $\begin{array}{l}\text { Galaxaura oblungata (Ellis et Solander) } \\
\text { Lamouroux }\end{array}$ & Rhodophyta & $\begin{array}{l}\text { Sio } \\
\text { spi }\end{array}$ & $\begin{array}{l}\text { Schizoporella longirostris Huncks } \\
\text { Unidentified spirorbids }\end{array}$ & $\begin{array}{l}\text { Bryozoa } \\
\text { Annelida }\end{array}$ \\
\hline HCo & Hemimycale columella (Bowerbank) & Porifera & Ssc & Stypocaulon scoparium (Linnaeus) Kützing & Phaeophyta \\
\hline$H d i$ & Halopteris diaphana (Heller) & Cnidaria & Sse & Sertella septentrionalis Harmer & Bryozoa \\
\hline Hfi & Halopteris flicina (Grateloup) Kutzing & Phaeophyta & Sue & Serpula vermicularis Linnaeus & Annelida \\
\hline Hpa & Halocynthia papillosa (Linnaeus) & Chordata & Svu & Sargassum vulgare C. Agardh & Phaeopliyta \\
\hline Htu & $\begin{array}{l}\text { Halimeda tuna (Elits et Solander) } \\
\text { Lamouroux }\end{array}$ & Chlorophyta & $\begin{array}{l}\text { Vst } \\
\text { Vut }\end{array}$ & $\begin{array}{l}\text { Vermiliopsis striaticeps (Grube) } \\
\text { Valonia utricularisI (Roth) C. Agardh }\end{array}$ & $\begin{array}{l}\text { Annelida } \\
\text { Chlorophyta }\end{array}$ \\
\hline hyd & Unidentified hydroids & Cnidaria & Wpe & Wrangelia penicillata C. Agardh & Rhodophyta \\
\hline
\end{tabular}

carbonatic sediments (Fig. 3a). During the experimental time (11 d), about one-third of the planulae metamorphosed and the number of planulary polyps reflected the number of planulae present in the different sections of the dishes (Fig. 3b). The ratio between metamorphosed (settled) and crawling planulae was not significantly different in the 2 sections $(43.3 \pm 14.6$ and $4.5 .6 \pm 6 \%$ for quartz and carbonate respectively). 

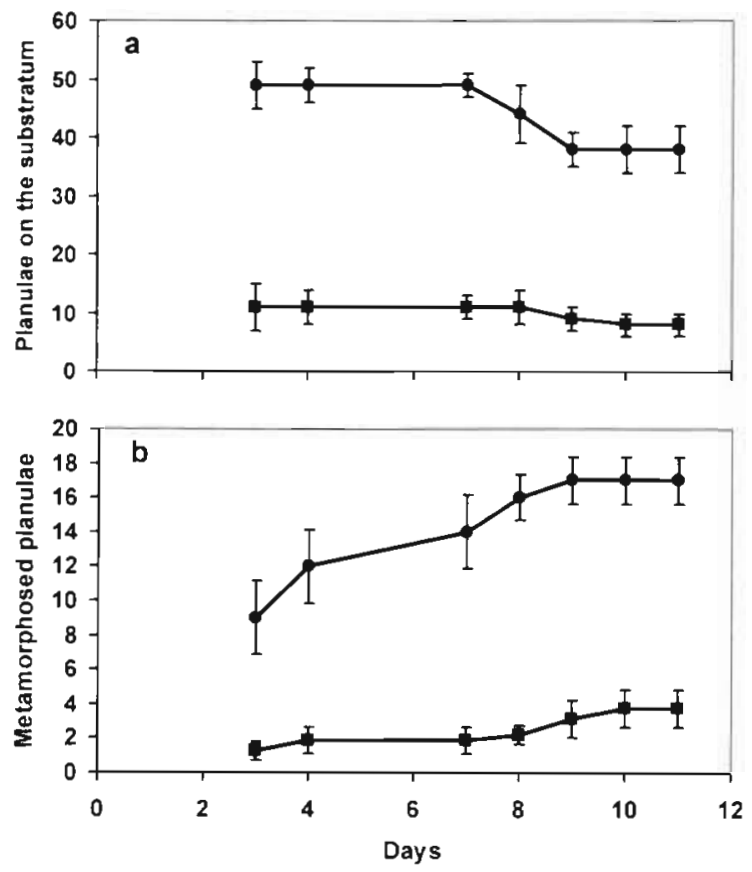

Fig. 3. Response of Eudendrium glomeratum planulae to differences in the mineral composition of the substrate. (a) Num-

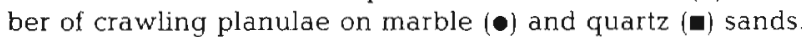
(b) Number of metamorphosed planulae on the same substrates. Data are the means \pm SE of 4 replicates

Field

The first 2 axes extracted from the correspondence analyses on the 3 data sets were significant in all cases ( $p<0.05$ according to the tables of Lebart 1975). The fraction of the total variance represented on the plane formed by the first 2 axes was $45.73 \%$ for the Ligurian Sea data set, $43.84 \%$ for Giglio Island, and $32.00 \%$ for northeast Sardinia.

Correspondence analysis on Ligurian Sea infralittoral epibenthic communities showed, along the 1st axis, a clear-cut separation of the stations of Gallinaria Island from those of the Portofino region, the first site being mainly characterised by quartzitic rock and the second by different rock types (Fig. 4). Along the 2nd axis, the station points of Portofino region tended to spread around according to the nature of their rocky bottoms, marl limestone separating at one extreme and sandstone at the other. This last arrangement might also reflect an exposure gradient, sandstone stations being located at more exposed sites that the limestone ones. However, there were station points of equally exposed sites of Gallinaria, all on quartzitic rock, which remained well separated from the corresponding ones of Portofino. Mean species richness on the quartzitic rocks of Gallinaria was lower than on the non-quartzitic rocks of the Portofino region (Fig. 5a):

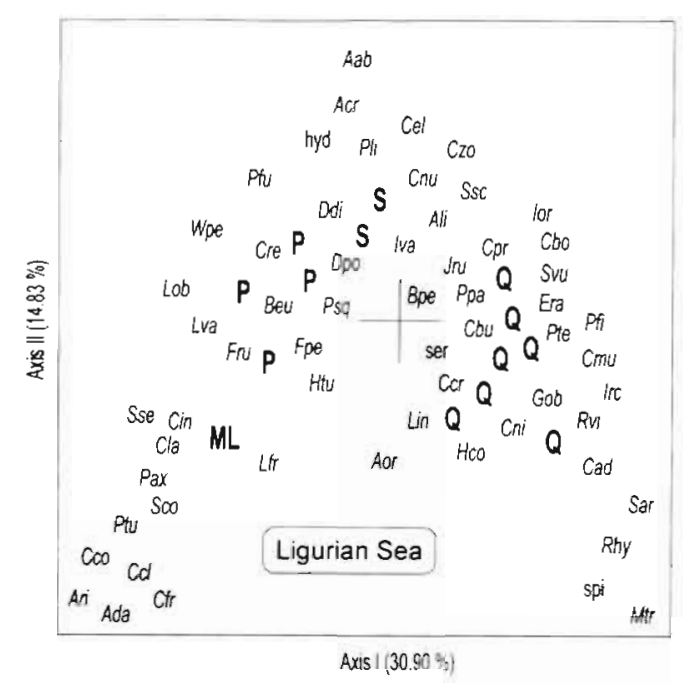

Fig. 4. Correspondence analysis on sublittoral rocky bottom data in the Ligurian Sea (Portotino region and Gallinaria Island). The variance fraction explained by the first 2 axes is indicated. Station points are identified by bold capital letters according to the nature of the rock. Q: quartzite; $S$ : sandstone; ML: marl limestone; P: puddingstone. Species points are identified by codes as in Table 2
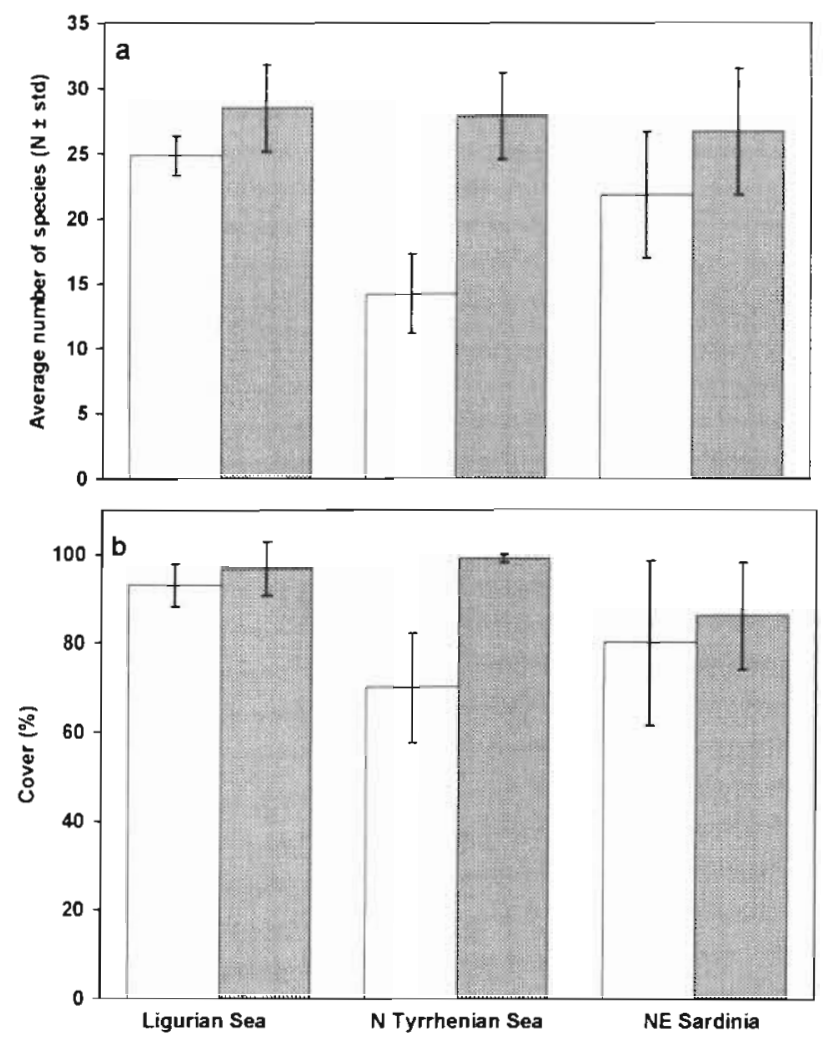

Fig. 5. Mean ( \pm 1 standard deviation) number of species (a) and total substratum cover (b) of the epibenthic assemblages in the 3 study sites, according to rock mineralogy. For each site, quartz-rich rocks (quartzite or granites) ( $\square$ ), and rocks poor in or deprived of quartz (E) are represented 


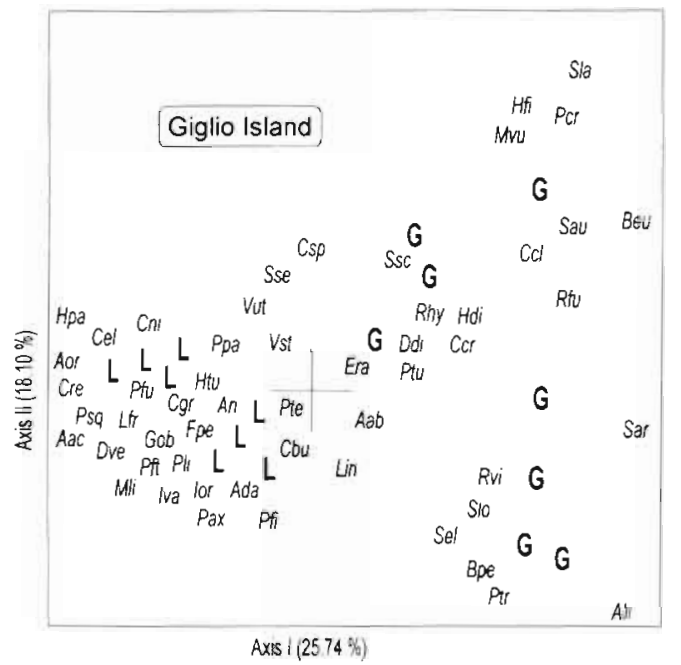

Fig. 6. Correspondence analysis on sublittoral rocky bottom data at Giglio Island (northern Tyrrhenian Sea). The variance fraction explained by the first 2 axes is indicated. Station points are identified by bold capital letters according to the nature of the rock. G: granite; L: limestone. Species points are identified by codes as in Table 2

this difference is significant (1-way ANOVA, $\mathrm{p}=$ 0.024 ). On the contrary, total substratum cover (Fig. 5b) was not significantly different ( $\mathrm{p}=0.119$ ).

Results from correspondence analysis on infralittoral communities of Giglio Island showed a separation of stationpoints along the 1 st axis that was consistent with the mineralogical nature of the rock, opposing limestone to granite (Fig. 6). On the 2nd axis, limestone station points were closely grouped, whereas granite station points were more scattered. Looking at the species points (see Table 2 for decoding species names), the 2nd axis opposed encrusting invertebrates to algae and erect or massive invertebrates: the first assemblage was considered the result of excess sea-urchin grazing by Balduzzi et al. (1996). Both the number of species (Fig. 5a) and total cover (Fig. 5b) were severely reduced on granite as compared with limestone (1-way ANOVA, $p<0.001$ in both cases).

Correspondence analysis on circalittoral epibenthic communities of northeastern Sardinia (Tavolara and Molara Archipelagoj showed again the separation between carbonate (limestone-dolomite) and granite station points (Fig. 7). On the contrary, no relationship was evident with depth. notwithstanding the comparatively great range investigated ( 18 to $34 \mathrm{~m}$ ). Also in this case, the number of species on granite was lower than on limestone-dolomite (Fig. 5a) and, although small, the difference was significant (1-way ANOVA, $\mathrm{p}=$ $0.043)$. In contrast, no difference was found for total cover $(p=0.717)$.

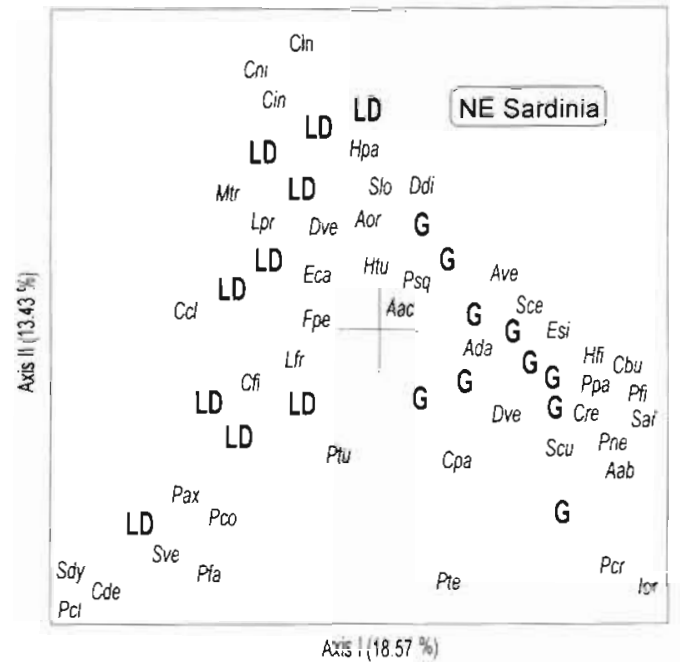

Fig. 7. Correspondence analysis on sublittoral rocky bottom data in northeastern Sardinia (Tavolara and Molara Archipelago). The variance fraction explained by the first 2 axes is indicated. Station points are identified by bold capital letters according to the nature of the rock. G: granite; LD: limestonedolomite. Species points are identified by codes as in Table 2

\section{DISCUSSION}

The structure of hard bottom communities has been traditionally interpreted as mainly the result of complex biotic interactions within adult assemblages (Connell 1983, Schoener 1983). Only in the last decade has the importance of external factors, such as physical processes and recruitment vagaries, been fully recognised (Barry \& Dayton 1991, Bingham 1992, Bianchi 1997, Guichard \& Bourget 1998, Smith \& Witman 1999). However, our knowledge about the role of the nature of substratum remains anecdotal. Many general papers on marine ecology report on the influence of hard substratum surface texture and physicochemical properties upon community composition and structure (Den Hartog 1972, Levinton 1982), but studies providing direct evidence are scarce. Comparing the epibiotic communities of different types of substratum, Connell \& Glasby (1999) found differences in the identity of species and the abundance of individual taxa. The same authors observed that the characteristics of the substratum surface were an important determinant in the structure of assemblages and that certain physical or chemical properties (e.g. alkalinity) may affect the settlement, growth or survival of organisms. On the other hand, Caffey (1982) found no effect of rock types on the settlement or survival of the intertidal barnacle Tesseropora rosea (Krauss).

Our experiments with the subticial hydroid Eudendrium glomeratum suggest that the larvae of benthic organisms could be selected, other environmental con- 
ditions being equal, by the mineral composition of the substrate and by the presence of quartz in particular Most hydroids are substrate generalists (Gili \& Hughes 1995) and species of Eudendrium are probably not exceptions (Sommer 1992). Our data for the first time demonstrate a strong choice of hydroid larvae against mineral substrates. In this choice no biological (presence of a bacterial film) or physical (roughness, grain shape) features may be invoked. The fact that after $11 \mathrm{~d}$ the ratio metamorphosed/crawling planulae in each dish section was not significantly different showed that, while the mineral nature of the substrate affects the larval behaviour, the metamorphosis into planulary polyps was not influenced. It is possible that the production of a perisarcal cover avoids any kind of negative interaction between the polyp and the substrate.

Our field data seem to suggest that the mineralogical properties of the substratum are long lasting, and continue to affect the established epibenthic communities. The contrast between rocks rich in or deprived of quartz always resulted evident on the first axis of correspondence analysis, indicating that this was the most important factor in differentiating the patterns of species composition and dominance. In all localities, the assemblages on quartz-rich rocks were less diverse and showed a simpler physiognomy. This could indicate the difficulty to reach a 'mature' condition in presence of quartz, which acts as an inhibiting factor. Cerrano et al. (1998) suggested that crystalline quartz has an evident negative effect on animals that colonise sands, probably due to both the oxidant properties of the crystal surface, generating silicon-based radicals, and to the formation of $\bullet \mathrm{OH}$ radicals in the surrounding aqueous environment (Marasas \& Harington 1960, Langer \& Nolan 1986, Shi et al. 1988, Vallyathan et al. 1988). In the case of rocky substrates, it seems reasonable to think that this inhibitory effect acts chiefly on the early stages of colonisation, perhaps via the microbial communities of the primary film (Wahl 1989, Johnson et al. 1997), and reduces as succession goes on. Many sessile organisms lay calcareous structures that in turn offer a secondary substrate to later colonists, thus annulling the effect of quartz. Most algae, for instance, are not influenced by the mineralogical nature of the rock (Cabioc'h et al. 1992) and, once developed, operate a 'biological conditioning' of the substrate, which has been considered as the most important factor structuring faunal communities (Abbiati et al. 1987, 1991, Simboura et al. 1995). Clearly, disturbance may disrupt biological cover (Sousa 1984), re-exposing organisms to the direct influence of the original substrate. This may explain why shallowwater sessile communities on quartz-rich rocks always appear in an early developmental phase, a fact com- monly interpreted as a consequence of intense seaurchin grazing (Navone et al. 1992, Balduzzi et al. 1996). However, there is no reason to think that sea urchins graze more heavily on granite that on limestone; rather, sea-urchin grazing should be considered as another form of disturbance that frees patches of the original substrate (Fanelli et al. 1994). In deeper water, sea urchins are less abundant and wave effects negligible. Disturbance is therefore less frequent and/or intense, and bio-mineralogy looses importance. Perhaps this is the reason why, in the whole Mediterranean Sea, the shallowest communities dominated by gorgonians, which are typical late-successional organisms, are found at greater depths on granite than on limestone (unpubl. obs.). Also, our data on circalittoral communities of northeast Sardinia showed that the difference in the number of species was not as great as for the shallower, infralittoral communities. Obviously, substratum stability is a consequence not only of depth but also of its intrinsic hardness and consistency, which are of direct importance with respect to wave action and bioboring. Hardness and consistency, which are in turn related to the mineralogical composition, should be higher in granite than in limestone, thus suggesting the reverse of the observed pattern.

In the study of ecological succession, Connell \& Slayter (1977) proposed 3 different mechanisms of interaction between organisms colonising hard substrates: facilitation, inhibition, and tolerance. We think that similar mechanisms might be recognised in the interaction between organisms and the substrate, which can facilitate, inhibit, or be neutral, not only to borers, but also to epilithic species, therefore affecting the development of communities.

Animals colonising sands and algae on rocks, as discussed above, might provide examples of inhibition by the substrate and of neutrality, respectively. A case of facilitation may occur when an organism, requiring high concentration of silica, uptakes this mineral directly from the substrate, instead of from the water. Gemmules of Spongilla lacustris L. reared in silica-free water may produce a complete spicular complement using different kinds of silicates laid down on the aquarium bottom as silica source (Jørgensen 1944). Volkmer-Ribeiro (pers. comm.) maintains that this phenomenon is also common in a natural environment: Brazilian fresh water sponges produce normal spicules in temporary water pools filled only by completely silica-free rain. In this habitat the only silica source is the quartzitic sand of the bottom of the pools and sedimented diatoms and spicules. To date, the biochemical mechanism allowing the dissolution and the uptake by sponges of particulate silica is not known. Nevertheless the marine sponge Chondrosia reniformis is able to collect and dissolve quartz grains (Bavestrello et al. 
1995b), probably due to a considerable production of ascorbic acid (Cerrano et al. 1999).

The results of this study and the above considerations suggest that bio-mineralogy is likely to play a major role on benthic communities, selecting the biota and affecting not only the initial colonisation, as seen in the experiment of Eudendrium settlement, but also later assemblages, as apparent from our field data. This potential role has been largely neglected to date and further studies are needed to prove its importance.

Acknowledgements. This research was financially supported by MURST Italian funds. Field activity received support from ENEA. Many thanks are due to all colleagues that helped during underwater work

\section{LITERATURE CITED}

Abbiati M, Bianchi CN, Castelli A (1987) Polychaete vertical zonation along a littoral cliff in the West Mediterranean. PSZN I: Mar Ecol 8\{1):33-48

Abbiati $M$, Bianchi $C N$, Castelli A, Giangrande A, Lardicci C (1991) Distribution of polychaetes on hard substrates of the midlittoral-infralittoral transition zone, western Mediterranean. Ophelia 5(suppl):421-432

Alvisi M, Bianchi CN, Colantoni P (1994) Le grotte sommerse dello Scoglio della Cappa (Isola del Giglio). Mem Ist Ital Speleologia Ser II 6:25-30

Anderson MJ, Underwood AJ (1994) Effects of substratum on the recruitment and development of an intertidal estuarine fouling assemblage. J Exp Mar Biol Ecol 184 $217-236$

Balduzzi A, Bianchi CN, Cattaneo-Vietti R, Cerrano C, Cocito $S$, Cotta S, Degl'Innocenti F, Diviacco G, Morgigni M, Morri C, Pansini M, Salvatori L, Senes L, Sgorbini S Tunesi L (1994) Primi lineamenti di bionomia bentica dell'Isola Gallinaria (Mar Ligure). In: Albertelli G, Cattaneo-Vietti R, Piccazzo M (eds) Atti del $10^{\circ}$ Congresso dell'Associazione Italiana di Oceanologia e Limnologia (AIOL), Genova, p 603-617

Balduzzi A, Bianchi CN, Burlando B, Cattaneo-Vietti R, Manconi R, Morri C, Pansini M. Pronzato R, Sarà M (1996) Zoobenthos di substrato duro delle isole di Capraia e del Giglio (Arcipelago Toscano). Atti Soc Toscana Sci Nat Mem Ser A 102 (Suppl)(1995):124-135

Barry JP, Dayton PK (1991) Physical heterogeneity and the organization of manine communities. In: Kolasa J, Pickett STA (eds) Ecological heterogeneity. Springer Verlag, New York, p 270-320

Bavestrello G, Cattaneo-Vietti R, Cerrano C, Danovaro R, Fabiano M (1995a) Annual sedimentation rates and role of the resuspension processes along a vertical cliff (Iigurian Sea, Italy). J Coastal Res 11(3):690-696

Bavestrello G, Arillo A, Benattj U, Cerrano C, Cattaneo-Vietti R, Cortesogno L, Gaggero L, Giovine M, Tonetti M, Sarà M (1995b) Quartz dicsolution by the cronge Chondrosia reniformis (Porifera, Dernospongiae). Nature 378:374-376

Bianchi CN (1997) Climate change and biological response in the marine benthos. In: Piccazzo M (ed) Atti del $12^{\circ}$ Congresso dell'Associazione Italiana di Oceanologia e Limnologia (AlOL), Vol 1. Genova, p 3-20

Bianchi CN, Morri C, Peirano A, Romeo G, Tunesi L. (1987) Bibliografia ecotipologica sul Mar Ligure. Ente per le nuove tecnologie, l'energie e l'ambiente, Coliana di studi ambientali, Roma

Bianchi CN, Cocito S, Morri C, Sgorbini S (1991) Rilevamento bionomico subacqueo. In: Abbiati $M$ (ed) Lezioni del corso formativo per ricercatore scientifico subacqueo. International School for Scientific Diving, Pisa, p 67-83

Bingham BL (1992) Life histories in an epifaunal community: coupling of adult and larval processes. Ecology 73: $2244-2259$

Boero F, Balduzzi A, Bavestrello G, Caffa B, Cattaneo Vietti R (1986) Population dynamics of Eudendrium glomeratum (Cnidaria, Anthomedusae) on the Portofino Promontory (Ligurian Sea). Mar Biol 92:81-85

Boni A, Braga G, Conti S, Gelati R, Marchetti G, Passeri LD (1969) Note illustrative della carta geologica d'Italia. Foglio 83, Rapallo. Foglio 94, Chiavari. Servizio Geologico d'Italia, Roma

Cabioc'h J, Floc'h JY, Le Toquin A, Boudouresque CF, Meinesz A, Verlaque M (1992) Guide des algues des mers d'Europe. Delachaux et Niestlé, Neuchátel

Caffey HMI (1982) No effect of naturally-occurring rock types on settlement or survival in the intertidal barnacle, Tesseropora rosea (Krauss). J Exp Mar Biol Ecol 63 $119-132$

Cattaneo-Vietti R, Sirigu AP, Tommei A (1988) Sea of Liguria, 2nd edn. Research Centre of the Union of Ligurian Chamber of Commerce, Genoa

Cerrano C, Bavestrello G, Cattaneo-Vietti R (1997) Light influence on planulae emission and settlement in Eudendrium glomeratum (Cnidaria, Hydrozoa). Biol Mar Medit $4(1): 30-33$

Cerrano C, Arillo A, Bavestrello G, Benatti U, Calcinai B. Cattaneo-Vietti R, Cortesogno L, Gaggero L, Giovine M, Puce S, Sarà M (1998) Organism-quartz interactions in structuring benthic communities: towards a marine bio-mineralogy? Ecol. Lett $2: 1-3$

Cerrano C, Bavestrello G, Arillo A, Benatti U, Bonpadre S, Cattaneo-Vietti R, Gaggero L, Giovine M, Leone L, Lucchetti G, Sarà M (1999) Calcium oxalate production in the marine sponge Chondrosia reniformis. Mar Ecol Prog Ser 179:297-300

Connell JH (1983) On the prevalence and relative importance of interspecific competition: evidence from field experiments. Am Nat 122:661-696

Connell JH, Slayter RO (1977) Mechanisms of succession in natural communities and their role in community stability and organization. Am Nat 111:1119-1144

Connell SD, Glasby TM (1999) Do urban structures influence local abundance and diversity of subtidal epibiota? A case study from Sidney Harbour, Australia. Mar Environ Res $47: 373-387$

Den Hartog C (1972) Substratum. In: Kinne O (ed) Marine Ecalogy, Vol 1, Part 3. Wiley-Interscience, p 1277-1289

Fanelli G, Piraino S, Belmonte G, Geraci S, Boero F (1994) Human predation along Apulian rocky coasts (SE Italy): desertification caused by Lithophaga lithophaga (Molluscal fisheries. Mar Ecol Piog Ser 110:1-8

Gili JM, Hughes RG (1995) The ecology of marine benthic hydroids. Oceanogr Mar Biol Annu Rev 33:351-426

Guichard F. Bourget E (1998) Topodraphic heterogeneity, hydrodynamics, and benthic community structure: a scale-dependent cascade. Mar Ecol Prog Ser 171:59-70

Hiscock K (1987) Subtidal tock and shallow sediments using diving. In: Baker JM, Wolff WJ (eds) Biological surveys of estuaries and coasts. Cambridge University Press, Cambridge, p 198-237

Holm ER, Cannon G, Roberts D. Schmidt AR, Sutherland JP, 
Rittschof D (1997) The influence of initial surface chemistry on development of the fouling community at Beaufort, North Carolina. J Exp Mar Biol Ecol 215:189-203

Johnson CR, Lewis TE, Nichols DS, Degnan BM (1997) Bacterial induction of settlement and metamorphosis in marine invertebrates. In: Lessios HA, Macintyre IG (eds) Proceedings of the 8th International Coral Reef Symposium. Smithsonian Tropical Research Institute, Panama, 2: $1219-1224$

Jørgensen CB (1944) On the spicule-formation of Spongilla lacustris (L.). 1 The dependence of the spicule formation on the content of dissolved and solid silicic acid of the milieu. Det Kgl Dansk Vidensk Selsk Biol Medd 19:2-45

Langer AM, Nolan RP (1986) Physicochemical properties of quartz controlling biological activity. In: Goldsmith DF, Winn DM, Shy CM (eds) Silica, silicosis, and cancer: controversy in occupational medicine. Praeger, New York

Lebart L (1975) Validité des résultats en analyse des données. Centre de recherches ef de documentation sur la consommation, Paris, LL/cd No 4465

Legendre P, Legendre L (1998) Numerical ecology. Second English edition. Dev Environ Model 20:1-853

Levinton JS (1982) Marine Ecology. Prentice-Hall, Englewood Cliffs, NJ

Lorenzoni GG, Chiesura-Lorenzoni F (1973) Considerazioni conservazionistiche sulle isole di Tavolara, Molara, Molarotto e relativa costa sarda. In: Scalera-Liaci L (ed) Atti del III simposio nazionale sulla conservazione della natura, Vol 2. Cacucci, Bari, p 409-435

Marasas LW, Harington JS (1960) Some oxydative and hydroxylative action of quartz: their possible relationship to the development of silicosis. Nature 188:1173-1174

McGuiness KA (1989) Effects of some natural and artificial substrata on sessile marine organisms at Galeta Reef, Panama. Mar Ecol Prog Ser 52:201-208

Morri C, Bianchi CN, Damiani V, Peirano A, Romeo G, Tunesi L (1988) L'ambiente marino tra Punta della Chiappa e Sestri Levante (Mar Ligure): profilo ecotipologico e proposta di carta bionomica. Boll Mus Ist Biol Univ Genova 52 (Suppl):213-231

Navone $A$, Bianchi $C N$, Orrù $P$, Ulzega $A$ (1992) Saggio di cartografia geomorfologica e bionomica nel parco marino di Tavolara - Capo Coda Cavallo. Oebalia 17(2)(Suppl): $469-478$

Orsino F (1975) Flora e vegetazione delle isole Gallinara e Bergeggi (Liguria occidentale). Webbia 29:595-644

Pomponi SA (1979) Ultrastructure of cells associated with

Editorial responsibility: Otto Kinne (Editor),

Oldendorf/Luhe, Germany excavation of calcium carbonate substrates by boring sponges. J Mar Biol Assoc UK 59:777-784

Russo GF, Cicogna F (1992) Exploitation of the date mussel, Lithophaga lithophaga: problems and prospects. Boll Mus Ist Biol Univ Genova 56-57 (1990-1991):184-194

Rützler R, Rieger G (1973) Sponge burrowing: fine structure of Cliona lampa penetrating calcareous substrata. Mar Biol 21:144-162

Schoener TW (1983) Field experiments on interspecific competition. Am Nat 122:240-285

Shi X, Dalal NS, Vallyathan V (1988) ESR evidence for the hydroxyl radical formation in aqueous suspension of quartz particles and its possible significance to lipid peroxidation in silicosis. J Toxicol Environ Health 25:237-245

Simboura N, Zenetos A. Thessalou-Legaki M, Pancucci MA, Nicolaidou A (1995) Benthic communities of the infralittoral in the N. Sporades (Aegean Sea): a variety of biotopes encountered and analysed. PSZN I: Mar Ecol $16(4): 283-306$

Smith F, Witman JD (1999) Species diversity in subtidal landscapes: maintenance by physical processes and larval recruitment. Ecology 80(1):51-69

Sommer C (1992) Larval biology and dispersal of Eudendrium racemosum (Hydrozoa, Eudendriidae). In: Bouillon J, Boero F, Cicogna F, Gili JM, Hughes RG (eds) Aspects of hydrozoan biology. Sci Mar 56:205-211

Sousa WP (1984) The role of disturbance in natural communities. Annu Rev Ecol Syst 15:353-391

Tortonese E (1958) Bionomia marina della regione costiera fra Punta della Chiappa e Portofino (Riviera ligure di levante). Archo Oceanogr Limnol 11(2):167-210

Tortonese E (1962) Recenti ricerche sul benthos in ambienti litorali del Mare Ligure. Pubbl Staz Zool Napoli 32 (Suppl):99-116

Underwood A.J (1997) Experiments in ecology. Cambridge University Press, Cambridge

Vallyathan V, Shi X, Dalal NS, I W, Castranova V (1988) Generation of free radicals from freshly fractured silica dust: potential role in acute silica-induced lung injury. Am Rev Respir Dis 138:1213-1219

Wahl M (1989) Marine epibiosis. 1. Fouling and antifouling: some basic aspects. Mar Ecol Prog Ser 58:175-189

Walters LJ, Wethey DS (1996) Settlement and early post-settlement survival of sessile marine invertebrates on topographically complex surfaces: the importance of refuge dimension and adult morphology. Mar Ecol Prog Ser 137 : $161-171$

Submitted: February 26, 1999; Accepted: September 21, 1999 Proofs received from author(s): February 14, 2000 